ENTITA : Jurnal Pendidikan Ilmu Pengetahuan Sosial dan Ilmu-Ilmu Sosial
http://ejournal.stainpamekasan.ac.id/index.php/entita
P-ISSN:2715-7555 E-ISSN:2716-1226

\title{
Analisis Pengaruh Jumlah Penduduk Perempuan Terhadap Indeks Pembangunan Manusia
}

\author{
Faraniena Yunaeni Risdiana \\ IAIN Madura \\ faranienayunaeni@gmail.com
}

\begin{abstract}
This study aims to determine the effect of the female population on the human development index in the province of East Java in 2017. This study uses quantitative methods with data collection techniques used are secondary data from the East Java Central Statistics Agency. From the research results it can be concluded that the total female population has almost no influence on the Human Development index. The human development index can be increased by improving the health sector, the economic sector and the education sector through the role of women, because the number of women population is almost the same as the number of men

Keywords: female population, HDI, East Java

Abstrak

Penelitian ini bertujuan untuk mengetahui pengaruh jumlah penduduk perempuan terhadap indeks pembangunan manusia di provinsi jawa timur tahun 2017. Penelitian ini menggunakan metode kuantitatif dengan teknik pengumpulan data yang digunakan adalah data sekunder dari Badan Pusat Statistik Jawa Timur. Dari hasil penelitian dapat disimpulkan bahwa jumlah penduduk perempuan memiliki hampir tidak memiliki pengaruh terhadap indeks Pembangunan Manusia. Indeks Pembangunan manusia dapat ditingkatkan dengan memperbaiki sektor kesehatan, sektor ekonomi dan sektor pendidikan melalui peran perempuan, dikarenakan jumlah penduduk perempuan yang hampir sama dengan jumlah penduduk laki-laki.
\end{abstract}

Kata Kunci: Penduduk Perempuan, IPM, Jawa Timur

Received: 2 November 2020; Revised:14 Desember 2020; Accepted: 17 Desember 2020

\begin{tabular}{lr}
\hline \hline (C) ENTITA : Jurnal Pendidikan IImu & http://doi.org/10.19105/ejpis. (c) (i) (5) \\
Pengetahuan Sosial dan Ilmu-llmu Sosial \\
Institut Agama Islam Negeri Madura, Indonesia
\end{tabular}




\section{Pendahuluan}

Pada 10 tahun terakhir indonesia memiliki tingat pertumbuhan penduduk yang cukup tinggi, yakni rata-rata setiap tahunnya adalah 1,5\%. Pertumbuhan penduduk ini berbanding lurus dengan pertambahan jumlah penduduk, baik jumlah penduduk perempuan maupun penduduk laki-laki. namun pertumbuhan penduduk yang cukup tinggi tidak beriringan dengan kesejahteraan. Padahal kesejahteraan adalah tujuan akhir dari sebuah pembangunan.

Masyarakat Indonesia masih memiliki permasalahan tentang kesetaraan gender, dimana masih adanya diskriminasi di tengah-tengah masyarakat. Diskriminasi gender dalam berbagai hal di kehidupan bermasyarakat menimbulkan perbedaan capaian antara laki-laki dan perempuan. Di wilayah yang masih kental akan budaya patriarki, perempuan umumnya lebih tertinggal dari laki-laki baik di bidang kesehatan, pendidikan dan ekonomi (kemenpppa:2019).

Indonesia dengan 33 provinsi pada periode tahun 2012-2014 menunjukkan indeks pembangunan manusia dan jumlah penduduk selalu meningkat, sementara tingkat kemiskinan dan tingkat pengangguran terbuka selalu menurun namun belum mencapai target RPJMN 2010- 2014 dan SDGs (David dan Bonivaus, 2017)

Konsep SDGs ini diperlukan sebagai kerangka pembangunan baru yang mengakomodasi semua perubahan yang terjadi pasca 2015, Millennium Development Goals(MDGs). Konsep SDGs melanjutkan konsep pembangunan Millenium Development Goals (MDGs) di mana konsep itu sudah berakhir pada tahun 2015. Jadi, kerangka pembangunan yang berkaitan dengan perubahan situasi dunia yang semula menggunakan konsep MGDs sekarang diganti SDGs. Adapun tiga pilar yang menjadi indikator dalam konsep pengembangan SDGs yaitu, pertama indikator yang melekat pembangunan manusia (Human Development), di antaranya pendidikan, kesehatan. Indikator kedua yang melekat pada lingkungan kecilnya (Social Economic Development), seperti ketersediaan sarana dan prasarana lingkungan, serta pertumbuhan ekonomi. (Wahyuningsih, 2017)

Tujuan Pembangunan Milenium atau Millenium Development Goals (disingkat MDGs) merupakan paradigma pembangunan global yang disepakati secara internasional oleh 189 negara anggota Perserikatan BangsaBangsa (PBB) dalam Konferensi Tingkat Tinggi (KTT) Milenium PBB bulan September 2000 silam. Sebagai salah satu negara yang ikut menandatangani Deklarasi MDGs, Indonesia mempunyai komitmen untuk 
melaksanakan program-program MDGs sebagai bagian yang tak terpisahkan dari program pembangunan nasional baik jangka pendek, menengah dan panjang (Juhardi 2011).

MDGs menempatkan pembangunan manusia sebagai fokus utama pembangunan sehingga nilai IPM menjadi salah satu indikator keberhasilan suatu wilayah/negara dalam melaksanakan MDGs. IPM digunakan untuk menilai kualitas pembangunan manusia, baik dari sisi dampaknya terhadap kondisi fisik manusia (kesehatan dan kesejahteraan) maupun yang bersifat non-fisik (pendidikan).

Pemodelan terhadap Indeks Pembangunan Manusia (IPM) Provinsi Jawa Timur menggunakan metode Regresi Logistik Ridge pernah diteliti leh dwi dan vita pada tahun 2015. Terdapat tiga variabel yang berpengaruh signifikan, yaitu angka kematian bayi, angka buta huruf dan angka partisipasi sekolah Dengan metode backward elimination, didapatkan model terbaik dengan ketepatan klasifikasi sebesar 97,37\% yang menghasilkan 5 kabupaten/kota tergolong IPM menengah bawah, yaitu Kabupaten Bangkalan, Sampang, Probolinggo, Situbondo dan Jember. Pada 33 kabupaten/kota yang lain tergolong dalam IPM menengah atas.

Pendidikan adalah suatu proses yang dilakukan oleh masyarakat dalam rangka meningkatkan kualitas sumber daya manusianya. Sehingga tingkat pendidikan dapat diartikan sebagai jenjang atau tingkat pendidikan yang ditempuh oleh masyarakat dalam rangka meningkatkan kualitas sumber daya manusia dengan ditandai diperolehnya ijazah.

Penelitian yang dilakukan Appleton (2001) menjelaskan bahwa kemiskinan yang terjadi di Uganda selama beberapa periode menjadikan kehidupan masyarakatnya terpuruk. Namun itu semua berakhir setelah adanya peningkatan tingkat pendidikan masyarakat. Dengan peningkatan pendidikan di sana membuat kehidupan masyarakat Uganda lebih berarti. Mereka memperoleh pekerjaan yang layak dengan upah yang sebanding. Sehingga mereka mampu meningkatkan kesejahteraan hidup mereka yang berdampak pada menurunnya kemiskinan.

Hasil penelitian yang sama juga dikemukakan oleh Doshi (2000) yang menyatakan bahwa pendidikan dapat mengurangi kemiskinan secara langsung yaitu dengan meningkatkan produktivitas bagi golongan miskin, memperbaiki kesempatan mereka untuk memperoleh pekerjaan dengan upah yang lebih baik. Dengan demikian pendidikan dapat mengurangi jumlah penduduk miskin yang ada. Tingkat pendidikan menjadi faktor penting yang mempengaruhi kemiskinan. Karena tingkat pendidikan akan mempengaruhi distribusi pendapatan yang pada akhirnya akan juga mempengaruhi 
kemiskinan. Jika semakin tinggi tingkat pendidikan maka distribusi pendapatan akan merata sehingga kemiskinan bisa berkurang. Menurut Sukirno (2006) pendapatan adalah jumlah penghasilan yang diterima oleh penduduk atas prestasi kerjanya selama satu periode tertentu, baik harian, mingguan, bulanan atau tahunan. Pendapatan merupakan dasar dari kemiskinan. Pendapatan setiap individu diperoleh dari hasil kerjanya. Sehingga tinggi rendahnya pendapatan akan dijadikan seseorang sebagai pedoman kerja. Mereka yang memiliki pekerjaan dengan gaji yang rendah cenderung tidak maksimal dalam berproduksi. Sedangkan masyarakat yang memiliki gaji tinggi memiliki motivasi khusus untuk bekerja dan produktivitas kerja mereka lebih baik dan maksimal. Tanpa mereka sadari bahwa tindakan mereka ini akan merugikan diri mereka sendiri, karena dari hasil produktivitas tersebut mereka akan memperoleh pendapatan (Teal, 2001).

Jawa Timur dengan jumlah penduduknya 39.292.972 Jiwa yang 50,6\% nya adalah terdiri dari perempuan dan sisanya adalah laki-laki. jumlah penduduk perempuan yang hampir sama dengan jumlah penduduk laki-laki diharapkan mampu memperbaiki indeks pembangunan Manusia.

Berdasarkan data Proyeksi Penduduk Indonesia 2010-2035 yang dilakukan oleh Badan Perencanaan Pembangunan Nasional dan Badan Pusat Statistik pada 2013, jumlah penduduk Jawa Timur mencapai 37,47 juta jiwa, atau tumbuh $8 \%$ dari hasil Sensus Penduduk 2000, yakni sebanyak 34,78 juta jiwa. Dalam proyeksi tersebut penduduk provinsi paling timur di Pulau Jawa tersebut akan mencapai 39,89 juta jiwa pada 2020.

Pada 2011, pertumbuhan penduduk Jawa Timur diproyeksikan sebesar $0,73 \%$ dan berangsur turun menjadi 0,61\% pada 2015. Kemudian pada 2020, pertumbuhan penduduk kembali turun menjadi hanya $0,47 \%$. Meningkatnya pendidikan masyarakat, pelaksanaan program Keluarga Berencana (KB), serta perubahan gaya hidup untuk menunda usia pernikahan dan mengatur jarak kelahiran membuat laju pertumbuhan cenderung turun.

Berdasarkan komposisi jenis kelamin, jumlah penduduk laki-laki di Jawa Timur mencapai 19,69 juta jiwa sementara perempuan 20,19 juta jiwa. Sedangkan berdasarkan komposisi umur, jumlah pneduduk usia 0-14 tahun sebesar $21,9 \%$ dari total jumlah penduduk, untuk usia 15-64 tahun sebesar 69,5\%, dan usia 65 ke atas sebesar 8,6\%. Kenaikan Jumlah penduduk diiringi dengan banyaknya pula penduduk yang berusia produktif di jawa timur. Diharapkan banyaknya jumlah penduduk yang produktif dapat meningkatkan kesejahteraan baik secara ekonomi, sosial dan kesehatan. 


\section{Metode Penelitian}

penelitian ini merupakan penelitian asosiatif atau hubungan yang bertujuan untuk mengetahui hubungan antara dua variabel atau lebih (Sugiyono, 2009). Metode yang digunakan adalah metode penelitian kuantitatif dengan regresi linier sederhana. . Data yang digunakan dalam penelitian ini merupakan data sekunder yang di dapat melalui situs resmi (laporan tahunan) Badan Pusat Statistik tahun 2017 yaitu 38 kabupaten dan kota. Fokus penelitian yang dilakukan dalam penelitian ini yaitu: (1) penelitian menggunakan model Regresi linier Sederhana. (2) penelitian didukung dengan bantuan program SPSS 20 (statistical product and service solutions) (3) variabel yang digunakan adalah Jumlah Penduduk Perempuan dan Indeks Pembangunan Manusia Provinsi Jawa Timur Tahun 2017.

Indeks Pembangunan Manusia Pada tahun 1990, UNDP memperkenalkan suatu indikator yang telah dikembangkannya, yaitu suatu indikator yang dapat menggambarkan perkembangan pembangunan manusia secara terukur dan representatif, yang dinamakan Human Development Index (HDI) atau Indeks Pembangunan Manusia (IPM). Angka IPM berkisar antara 0 hingga 100. Semakin mendekati 100, maka hal tersebut merupakan indikasi pembangunan manusia yang semakin baik. Berdasarkan nilai IPM, UNDP membagi status pembangunan manusia suatu negara atau wilayah ke dalam tiga golongan, yaitu:

1. $I P M<50$ (rendah)

2. $50 \leq \mathrm{IPM}<80$ (sedang/menengah)

3. $I P M \geq 80$ (tinggi)

IPM merupakan indeks komposit yang dihitung sebagai rata-rata sederhana dari tiga indeks dari dimensi yang menggambarkan kemampuan dasar manusia dalam memperluas pilihan-pilihan.

\section{Hasil Penelitian}

Dalam penelitian ini, langkah pertama yang dilakukan adalah mendeskripsikan data jumlah penduduk perempuan dan Indeks Pembangunan Manusia Provinsi Jawa Timur Tahun 2017.

Tabel 1. Data Jumlah Penduduk Perempuan dan IPM Jatim 2017

\begin{tabular}{cccc}
\hline No & Kabupaten/Kota & $\begin{array}{c}\text { J. Penduduk } \\
\text { Perempuan }\end{array}$ & IPM \\
1 & Pacitan & 283196 & 66,51 \\
2 & Ponorogo & 435101 & 69,26 \\
\hline
\end{tabular}




\begin{tabular}{|c|c|c|c|}
\hline 3 & Trenggalek & 348715 & 68,10 \\
\hline 4 & Tulungagung & 528274 & 71,24 \\
\hline 5 & Blitar & 575788 & 69,33 \\
\hline 6 & Kediri & 777803 & 70,47 \\
\hline 7 & Malang & 1281579 & 68,47 \\
\hline 8 & Lumajang & 530604 & 64,23 \\
\hline 9 & Jember & 1235689 & 64,96 \\
\hline 10 & Banyuwangi & 806306 & 69,64 \\
\hline 11 & Bondowoso & 394436 & 64,75 \\
\hline 12 & Situbondo & 346592 & 65,68 \\
\hline 13 & Probolinggo & 591503 & 64,28 \\
\hline 14 & Pasuruan & 809988 & 66,69 \\
\hline 15 & Sidoarjo & 1086588 & 78,70 \\
\hline 16 & Mojokerto & 550327 & 72,36 \\
\hline 17 & Jombang & 629664 & 70,88 \\
\hline 18 & Nganjuk & 527411 & 70,69 \\
\hline 19 & Madiun & 344300 & 70,27 \\
\hline 20 & Magetan & 322497 & 72,60 \\
\hline 21 & Ngawi & 424103 & 69,27 \\
\hline 22 & Bojonegoro & 628910 & 67,28 \\
\hline 23 & Tuban & 588822 & 66,77 \\
\hline 24 & Lamongan & 611177 & 71,11 \\
\hline 25 & Gresik & 647923 & 74,84 \\
\hline 26 & Bangkalan & 507105 & 62,30 \\
\hline 27 & Sampang & 491162 & 59,90 \\
\hline 28 & Pamekasan & 443515 & 64,93 \\
\hline 29 & Sumenep & 566916 & \\
\hline 30 & Kediri & 142394 & 77,13 \\
\hline 31 & Blitar & 70584 & 77,10 \\
\hline 32 & Malang & 436603 & 80,65 \\
\hline 33 & Probolinggo & 118301 & 72,09 \\
\hline 34 & Pasuruan & 99701 & 74,39 \\
\hline 35 & Mojokerto & 64692 & 76,77 \\
\hline 36 & Madiun & 90896 & 80,13 \\
\hline 37 & Surabaya & 1454517 & 81,07 \\
\hline 38 & Batu & 101412 & 74,26 \\
\hline
\end{tabular}

Sumber:BPS Jatim, 2018

Dari tabel 1 dapat dilihat bahwa jumlah penduduk perempuan terkecil adalah di mojokerto dengan jumlah penduduk perempuan 64.692 jiwa dengan IPM 72.36 dan jumlah penduduk perempuan paling banyak ada di Surabaya dengan total 1.454.517 jiwa dengan IPM 81,07. Kota Surabaya menunjukkan banyaknya jumlah penduduk perempuan 
memiliki IPM yang tinggi pula, sementara IPM terendah 59,90 yakni berada dikabupaten sampang dengan jumlah penduduk perempuan sebanyak 491.162 jiwa

Analisis selanjutnya yaitu uji korelasi antara jumlah penduduk perempuan dan IPM provinsi jawa timur tahun 2017, uji ini dilakukan untuk melihat adanya hubungan antar dua variabel penelitian. Hasil uji korelasi akan disajikan dalam tabel berikut.

Tabel 2. Analisis uji korelasi antara jumlah penduduk perempuan dan IPM

\begin{tabular}{ccccc}
\hline Model & $\mathrm{R}$ & $\mathrm{R}$ Square & $\begin{array}{c}\text { Adjusted R } \\
\text { Square }\end{array}$ & $\begin{array}{c}\text { Std. Error of the } \\
\text { Estimate }\end{array}$ \\
& & \multicolumn{4}{c}{$\begin{array}{c}121^{\mathrm{a}} \\
1\end{array}$} & .015 & -.013 & 5.41651 \\
\hline
\end{tabular}

Tabel 2 menampilkan nilai $\mathrm{R}$ yang merupakan simbol dari nilai koefisien korelasi. Pada contoh diatas nilai korelasi adalah 0,121 . Nilai ini dapat diinterpretasikan bahwa hubungan kedua variabel penelitian ada di kategori lemah. Melalui tabel ini juga diperoleh nilai $\mathrm{R}$ Square atau koefisien determinasi yang menunjukkan seberapa bagus model regresi yang dibentuk oleh interaksi variabel bebas dan variabel terikat. Nilai KD yang diperoleh adalah 1,5\% yang dapat ditafsirkan bahwa variabel bebas X1 memiliki pengaruh kontribusi sebesar 1,5\% terhadap variabel $Y$ dan 98,5\% lainnya dipengaruhi oleh faktorfaktor lain diluar variabel X1.

Analisis selanjutnya yaitu uji Anova antara jumlah penduduk perempuan dan IPM provinsi jawa timur tahun 2017, uji ini dilakukan untuk:

1. Menghitung nilai estimasi rata-rata dan nilai variabel terikat berdasarkan pada nilai variabel bebas.

2. Menguji hipotesis karakteristik dependensi

3. Meramalkan nilai rata-rata variabel bebas dengan didasarkan pada nilai variabel bebas diluar jangkaun sample.

Hasil uji regresi sederhana akan disajikan dalam tabel berikut:

Tabel 3. ANOVA

\begin{tabular}{ccccccc}
\hline \multicolumn{1}{c}{ Model } & Sum of Squares & df & & Mean Square & F & Sig. \\
Regression & 15.786 & 1 & 15.786 & .538 & $.468^{\text {b }}$ \\
Residual & 1056.190 & 36 & 29.339 & & \\
Total & 1071.975 & 37 & & & \\
\multicolumn{5}{c}{ a. Dependent Variable: IPM } \\
& b. Predictors: (Constant), Perempuan & & \\
\hline
\end{tabular}

ENTITA Vol. 2 No. 2, Desember 2020 
Pada Tabel 3 taraf signifikansi atau linieritas dari regresi. Kriterianya dapat ditentukan berdasarkan uji F atau uji nilai Signifikansi (Sig.). Cara yang paling mudah dengan uji Sig., dengan ketentuan, jika Nilai Sig. < 0,05, maka model regresi adalah linier, dan berlaku sebaliknya. Berdasarkan tabel ketiga, diperoleh nilai Sig. = 0,468 yang berarti $>$ kriteria signifikan $(0,05)$, dengan demikian model persamaan regresi berdasarkan data penelitian adalah tidak signifikan artinya, model regresi linier tidak memenuhi kriteria linieritas. artinya kenaikan variabel $X$ yakni jumlah penduduk perempuan tidak diikuti secara proporsional oleh kenaikan variabel Y yakni Indeks Pembangunan Manusia

Dalam Penelitian Ini jumlah penduduk perempuan tidak memiliki pengaruh terhadap Indeks Pembangunan Masyarakat,. Penambahan jumlah penduduk yang besar mempunyai implikasi yang sangat luas terhadap program pembangunan. Penduduk yang besar dengan kualitas sumber daya manusiayang relatif kurang memadai sangat berpotensi memberikan beban dalam pembangunan, yang tercermin dari beratnya beban pemerintah pusat dan pemerintah daerah untuk menyediakan berbagai pelayanan publik seperti pendidikan, kesehatan, perumahan, lapangan kerja dan lingkungan hidup (Arjoso 2005).

\section{Indeks Pembangunan Manusia}

IPM mempunyai tiga unsur yaitu kesehatan, pendidikan yang dicapai, dan standar kehidupan atau sering disebut ekonomi. Jadi ketiga unsur ini sangat penting dalam menentukan tingkat kemampuan suatu provinsi untuk meningkatkan IPMnya. Ketiga unsur tersebut tidak berdiri sendiri, melainkan saling memengaruhi satu sama yang lainnya. Selain itu juga dipengaruhi oleh faktor-faktor lain, seperti ketersediaan kesempatan kerja, yang pada gilirannya ditentukan oleh pertumbuhan ekonomi, infrastruktur dan kebijakan pemerintah. Jadi IPM di suatu daerah akan meningkat apabila ketiga unsur tersebut dapat ditingkatkan, nilai IPM yang tinggi menandakan keberhasilan pembangunan ekonomi di daerah tersebut. Misalkan:

1. Usaha harapan hidup (kesehatan), merupakan usia maksimal yang menjadi harapan manusia untuk bertahan hidup. Indeks pembangunan manusia dipengaruhi oleh usia harapan hidup. Salah satu indikator usia harapan hidup adalah aspek kesehatan, Contoh indikator usia harapan hidup seperti angka kematian bayi, rata-rata penduduk yang sakit, persentase penduduk sakit, persentase kelahiran bayi yang dibantu tenaga media, dan sebagainya; 
2. Pengetahuan (pendidikan), merupakan faktor yang mempengaruhi indeks pembangunan manusia. Indikator dari pengetahuan atau pendidikan antara lain: ratarata lama waktu bersekolah, angka melek huruf, angka anak putus sekolah, dan sebagainya.

3. Standar hidup layak (ekonomi), merupakan faktor yang mempengaruhi indeks pembangunan manusia yang berkaitan dengan aspek ekonomi. Indikator standar hidup layak antara lain: jumlah penduduk yang bekerja, jumlah penduduk miskin, jumlah pengangguran terbuka, dan sebagainya.

\section{Jumlah Penduduk Perempuan}

jumlah penduduk perempuan apabila mengalami kenaikan yang sangat tinggi dengan tidak diikuti dengan kenaikan pendidikan, standar hidup dan usaha harapan hidup justru dapat menurunkan indeks pembangunan manusia Pertumbuhan penduduk sebenarnya merupakan keseimbangan dinamis antara dua kekuatan yang menambah atau yang mengurangi jumlah penduduk. Perkembangan penduduk akan dipengaruhi oleh jumlah bayi yang lahir tetapi secara bersamaan pula akan dikurangi oleh jumlah kematian yang dapat terjadi pada semua golongan umur. Dalam konteks spasial moblitas penduduk juga berpengaruh terhadap perubahan dalam jumlah penduduk, dimana imigrasi akan menambah jumlah penduduk dan emigrasi akan mengurangi jumlah penduduk dalam suatu wilayah. Jumlah penduduk yang besar bagi beberapa kalangan merupakan suatu hal positif karena dengan jumlah penduduk yang besar tersebut dapat dijadikan sebagai subjek pembangunan, perekonomian akan berkembang bila jumlah tenaga kerjanya banyak. Namun disisi lain beberapa kalangan justru meragukan apakah jumlah penduduk yang besar adalah sebagai asset seperti yang dijelaskan sebelumnya, akan tetapi kebalikan dari hal tersebut bahwa penduduk merupakan beban bagi pembangunan. (Rochaida, 2016)

Hal ini berkaitan dengan pemenuhan kebutuhan yang semakin lama semakin banyak pula seiring dengan perkembangan jumlah penduduk tersebut. Pandangan pesimis seperti ini di dukung oleh teori Malthus yang menyatakan bahwa pertumbuhan penduduk menurut deret ukur sementara pertumbuhan bahan makanan menurut deret hitung. Simpulan dari pandangan pesimis ini adalah bukan kesejahteraan yang didapat tapi justru kemelaratan akan di temui bilamana jumlah penduduk tidak dikendalikan dengan baik. Sebenarnya permasalahan yang muncul dididang kependudukan bukan hanya pada jumlah yang besar semata akan tetapi juga berimbas pada turunan dari 
kuantitas yang besar tersebut antara lain adalah persebaran penduduk, kualitas penduduk, kecukupan dari sisi konsumsi, struktur penduduk yang sebagian besar masih muda, modal dan teknologi yang dimiliki juga masih rendah dan akibatnya produktivitas kerja makin menurun serta masalah krusial yang berkaitan dengan ketenagakerjaan.

Dari sisi lain yakni angka harapan hidup yang berkaitan dengan unsur kesehatan. Angka Harapan Hidup Mils dan Gilson (1990) dalam Dimas (2010) mendefinisikan ekonomi kesehatan sebagai penerapan teori, konsep dan teknik ilmu ekonomi pada sektor kesehatan, sehingga dengan demikian ekonomi kesehatan berkaitan erat dengan hal-hal yaitu alokasi sumber daya di antara berbagai upaya kesehatan, jumlah sumber daya yang di gunakan dalam pelayanan kesehatan, pengorganisasian dan pembiayaan dari berbagai pelayanan kesehatan, efisiensi pengalokasian dan penggunaan berbagai sumber daya dan dampak upaya pencegahan, pengobatan, dan pemulihan kesehatan pada individu dan masyarakat. Mils dan Gilson (1990) dalam Dimas (2010) mendefinisikan ekonomi kesehatan sebagai penerapan teori, konsep dan teknik ilmu ekonomi pada sektor kesehatan, sehingga dengan demikian ekonomi kesehatan berkaitan erat dengan hal-hal yaitu alokasi sumber daya di antara berbagai upaya kesehatan, jumlah sumber daya yang di gunakan dalam pelayanan kesehatan, pengorganisasian dan pembiayaan dari berbagai pelayanan kesehatan, efisiensi pengalokasian dan penggunaan berbagai sumber daya dan dampak upaya pencegahan, pengobatan, dan pemulihan kesehatan pada individu dan masyarakat. Angka Harapan Hidup $(\mathrm{AHH})$ merupakan alat untuk mengevaluasi kinerja pemerintah dalam meningkatkan kesejahteraan penduduk pada umumnya, dan meningkatkan derajat kesehatan pada khususnya. Angka Harapan Hidup menggambarkan umur ratarata yang dicapai seseorang dalam situasi mortalitas yang berlaku di lingkungan masyarakatnya. Untuk Angka Harapan Hidup yang rendah di suatu daerah menunjukkan pembangunan kesehatan belum berhasil, dan semakin tinggi $\mathrm{AHH}$ semakin menunjukkan keberhasil pembangun kesehatan di daerah tersebut.

Tingkat Pendidikan Pertumbuhan ekonomi adalah suatu kenaikan output perkapita dalam jangka panjang. Dalam pengertin ini teori harus mencakup teori mengenai GDP dan teori mengenai pertumbuhan penduduk. Salah satu faktor yang mempengaruhi pertumbuhan ekonomi yang ada di beberapa negara atara lain: kekayaan sumber daya alam dan tanahnya, jumlah dan mutu tenaga kerja, barang - barang modal yang tersedia, tingkat teknologi yang digunakan dan system sosial dan sikap masyarakat. 266

ENTITA Vol. 2 No. 2, Desember 2020 
Sistem pendidikan Indonesia terdiri dari beberapa tingkatan pendidikan. Tingkat pendidikan adalah suatu proses jangka panjang yang menggunakan prosedur sistematis dan terorganisir, yang mana tenaga kerja manajerial mempelajari pengetahuan konseptual dan teoritis untuk tujuan-tujuan umum. Ukuran dasar tingkat pendidikan adalah tahun sebelumnya. Perkembangan tersebut selalu dinyatakan dalam bentuk persentase perubahan pendapatan nasional pada suatu tahun tertentu dibandingkan dengan tahun sebelumnya.

Pendidikan merupakan salah satu cara untuk meningkatkan kualitas sumber daya manusia. Melalui pendidikan, pengetahuan seseorang akan bertambah yang akan bermanfaat untuk mempelajari keterampilan yang berguna di dunia kerja. Dengan demikian pendidikan dapat dimasukkan sebagai investasi pembangunan yang hasilnya dapat dinikmati di kemudian hari. Sebagaimana pembangunan di bidang lain, pendidikan menjadi salah satu bidang utama selain kesehatan dan ekonomi (BPS, 2013)

Menurut Badan Pusat Statistik (2013) pendidikan tertinggi yang ditamatkan, yaitu jenjang pendidikan tertinggi yang ditamatkan seseorang yang ditandai dengan ijazah. Persentase pendidikan yang ditamatkan dapat digunakan sebagai acuan perencanaan pembangunan yang digunakan untuk melakukan perencanaan penawaran tenaga kerja dengan menyesuaikan kualifikasi pendidikan yang ditamatkan oleh angkatan kerja di suatu wilayah.

Berdasarkan beberapa definisi di atas dapat disimpulkan bahwa pendidikan adalah suatu proses yang dilakukan oleh masyarakat dalam rangka meningkatkan kualitas sumber daya manusianya. Sehingga tingkat pendidikan dapat diartikan sebagai jenjang atau tingkat pendidikan yang ditempuh oleh masyarakat dalam rangka meningkatkan kualitas sumber daya manusia dengan ditandai diperolehnya ijazah

Tingkat pendidikan terhadap jumlah penduduk miskin tidak memiliki pengaruh signifikan bukan hanya karena jumlah penduduk yang menurun, selain itu penduduk yang selesai menamatkan sekolahnya tidak semua bisa bekerja. Kebanyakan dari mereka memiliki keinginan bekerja menjadi karyawan kantor terlebih bagi mereka yang lulusan perguruan tinggi. Sedangkan lapangan kerja yang mereka inginkan jumlahnya terbatas. Sehingga tidak semua lulusan bisa bekerja yang secara tidak langsung akan menyebabkan kemiskinan. 
Kemiskinan disebabkan oleh banyak faktor, diantaranya dapat disebabkan oleh karena sulitnya memenuhi kebutuhan dasar, sulitnya memperoleh pendidikan dan pekerjaan. Sulitnya seseorang dalam memperoleh pendidikan akan menyebabkan seseorang kesulitan dalam mencari pekerjaan. Seiring perkembangan zaman lapangan kerja yang tersedia akan mencari tenaga kerja yang memiliki tingkat pendidikan yang tinggi. Jika dalam masa pendidikan banyak masyarakat yang tidak menempuh sebagaimana mestinya maka masyarakat tersebut akan mengalami kesulitan untuk mencari pekerjaan. Kesulitan mencari pekerjaan ini akan mengakibatkan seseorang kesulitan memperoleh pendapatan. Sehingga mereka tidak mampu untuk memenuhi kebutuhan hidup mereka.

Nurkse (dalam Kuncoro, 2006) menggambarkan dalam teori lingkar kemiskinan bahwa keterbelakangan, ketidaksempurnaan pasar, dan kurangnya modal dapat mengakibatkan rendahnya produktivitas manusia. Rendahnya produktivitas manusia akan mengakibatkan rendahnya pendapatan yang diterima. Rendahnya pendapatan yang diterima akan berakibat pada rendahya tabungan dan rendahnya investasi. Investasi bisa berupa investasi sumber daya manusia yaitu dengan ukuran pendidikan, maupu investasi kapital dengan ukuran konsumsi. Berdasarkan teori lingkaran kemiskinan tersebut dapat diketahui ada beberapa faktor yang menyebabkan kemiskinan diantaranya tingkat pendapatan, tingkat pendidikan, dan besarnya konsumsi.

Aspek pendapatan yang dapat digunakan sebagai indikator kemiskinan adalah pendapatan perkapita (Suryana, 2000). Pendapatan perkapita adalah pendapatan rata-rata penduduk suatu negara pada suatu periode tertentu, yang biasanya satu tahun. Pendapatan perkapita juga bisa diartikan sebagai jumlah dari nilai barang dan jasa rata-rata yang tersedia bagi penduduk suatu negara pada suatu periode tertentu. Pendapatan perkapita diperoleh dari pedapatan nasional pada tahun tertentu dibagi dengan jumlah penduduk suatu negara pada tahun tersebut (Sukirno, 2004). Berdasarkan beberapa penjelasan diatas maka pendapatan yang dimaksud dalam penelitian ini adalah pendapatan penduduk suatu daerah yaitu Provinsi Jawa Timur yang diukur dari pendapatan perkapita.

Hasil temuan Singh (2012) menyatakan bahwa pendapatan seseorang mampu menurunkan kemiskinan di suatu negara. Seperti yang ada di negara Asia bahwa pada tahun 1990 beberapa negara di Asia mengalami penurunan jumlah 268 
kemiskinan. Yang sebagian besar disebabkan karena adanya peningkatan dalam hal pendapatan. Demikian pula temuan dari Janjua (2011) yang menyatakan bahwa peningkatan pendapatan dapat menurunkan jumlah penduduk miskin. Karena dengan peningkatan pendapatan masyarakat bisa meningkatkan dalam hal pemenuhan kebutuhannya. Sehingga kesejahteraan masyarakat meningkat dan jumlah penduduk miskinnya menurun. Salah satu tujuan ekonomi adalah untuk menjelaskan dasar-dasar perilaku konsumen. Mendalami tentang hukum permintaan dan mengetahui bahwa orangorang lebih cenderung membeli banyak barang ketika harga barang itu rendah dan sebaliknya (Samuelson, 2004). Konsumsi secara umum diartikan sebagai penggunaan barang dan jasa secara langsung untuk memenuhi kebutuhan manusia (Rosydi, 2002). Keynes mengemukakan bahwa konsumsi adalah fungsi positif dari pendapatan dan rumah tangga yang berpendapatan tinggi melakukan konsumsi pangan lebih sedikit dari rumah tangga yang berpendapatan rendah, karena pendapatannya yang lain dialokasikan pada konsumsi non pangan (dalam Case and Fair, 2002)

\section{Kesimpulan}

Analisis diatas terlihat bahwa jumlah penduduk perempuan tidak memiliki pengaruh yang signifikan terhadap indeks pembangunan manusia provinsi jawa timur. Jumlah penduduk perempuan yang hampir sama dengan jumlah penduduk laki-laki apabila perempuan dibangun melalui pendidikan, perempuan dan kemiskinan serta perempuan dan kesehatan akan memiliki pengaruh terhadap indeks pembangunan manusia di jawa timur. Untuk penelitian selanjutnya gunakan faktor yang memiliki pengaruh terhadap 3 unsur penting tersebut misalkan dalam bidang kesehatan gunakan faktor jumlah banyaknya fasilitas kesehatan, jumlah dokter dll, sementara dalam bidang ekonomi gunakan faktor rata-rata pendapatan per rumah tangga/ pribadi dalam satu tahun. Sementara dalam bidang pendidikan gunakan faktor pendidikan terakhir, jumlah anak yang sekolah dan angka melek huruf.

\section{Daftar Pustaka}

Arjoso. 2005. Rencana Strategis BKKBN. Jakarta : Pusat Pendidikan dan Pelatihan BKKBN

BPS. 2013. PDRB Provinsi Jawa Timur. Jawa Timur: BPS.

Case, K., \& Fair, R. 2002. Principle Of Economic. Jakarta: Prenhalindo 
Janjua, Pervez Zamurrad 2011. The Role of Education and Income in Poverty Alleviation. The Lahore Journal of Economics, Vol. 16, No. 1, (PP: 143172).

Kemenpppa, dan BPS,. 2019. Pembangunan Manusia Berbasis Gender 2019. Jakarta: Kemenpppa

Kristianto, David dan Bonivasius Prasetya. Pengaruh Jumlah Penduduk, IPM, dan TPT terhadap Kemiskinan (Pendekatan Moneter dan Multidimensi) di Indonesia" October 2017. DOI: 10.13140/RG.2.2.22675.99367

Kuncoro, M. 2006. Ekonomika Pembangunan: Teori, Masalah dan Kebijakan. Yogyakarta: UPP STIM YKPN

Rochaida, Eny. 2016. Dampak Pertumbuhan Penduduk Terhadap Pertumbuhan Ekonomi Dan Keluarga Sejahtera Di Provinsi Kalimantan Timur. Forum Ekonomi; Volume 18 No 12016

Rosydi, Suherman. 2002. Pengantar Teori Ekonomi. Jakarta: Raja Grafindo Persada.

Samuelson, Paul. 2004. Mikro Ekonomi. Jakarta : Erlangga.

Singh, R. 2012. Human Development Index and Poverty Linkages. International Journal of Marketing and Technology, Vol. 2 No. 5, (PP: 219-288)

Suryana. 2000. Ekonomi Pembangunan. Jakarta: Salemba Empat

Sukirno, S. 2004. Pengantar Teori Makro Ekonomi. Jakarta: Raja Grafindo Persada.

Sugiyono,prof,DR. 2009. Statistika untuk Penelitian. Bandung: Alfabeta

Wahyuningsih. Millenium Develompent Goals (Mdgs) Dan Sustainable Development Goals (Sdgs) Dalam Kesejahteraan Sosial". Jurnal Bisnis dan Manajemen. Vol 11 No 3 September 2017

Juhardi R.R, Hamidi, W., \& Syapsan. 2011) Studi Empiris Capaian MDGs di Provinsi Riau. Jurnal Sosial Ekonomi Pembangunan. I (3), 272-289. 